
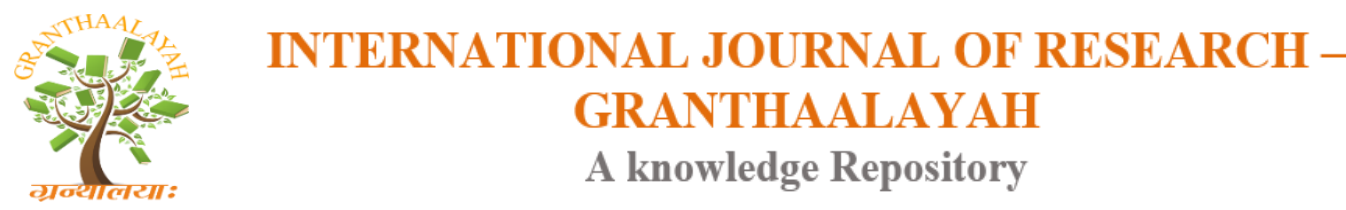

Science

\title{
A CASE STUDY ON THE AYURVEDIC MANAGEMENT OF BAHUPITTA KAMALA WSR JAUNDICE
}

\author{
Dr. Vaishnavi Narahari Saka ${ }^{1}$, Dr. Vivek S. Chandurkar ${ }^{2}$ \\ ${ }^{1}$ M.D.(Scholar), Kayachikitsa Department SGR Ayurved Mahavidyalaya, Solapur, India \\ ${ }^{2}$ M.D.(Kaychikitsa) Professor and HOD of Kaychikitsa Department SGR Ayurved \\ Mahavidyalaya, Solapur, India
}

\begin{abstract}
Modern culture and advanced technology have made life comfortable, but it's given invitation to many diseases. In fast life style of people are leading irregular eating habits, eating outside has become fashion which increased risk of contaminated food and water. All these etiological factors lead to risk of related disorders. Bahupitta kamla is one of important disease. Jaundice is a condition in which yellowness of skin, sclera, mucus membrane, and excretions occurs due to hyperbilirubinemia and depositions of bile pigments.

Jaundice is described as kamala vyadhi in Ayurveda. IN ayurvedic samhita description of kamala is given in detail. The description of hepatocellular jaundice is similar to ayurvedic description of kamala vyadhi. Here a case report of a 30 years male having Bahupitta Kamala (Jaundice) who was treated with ayurvedic medicine and some panchakarma which give effective results with ayurvedic management.
\end{abstract}

Keywords: Hyperbilirubinemia; Bahupitta Kamla; Hepatocellular Jaundice; Ayurvedic Management.

Cite This Article: Dr. Vaishnavi Narahari Saka, and Dr. Vivek S. Chandurkar (2018). "A CASE STUDY ON THE AYURVEDIC MANAGEMENT OF BAHUPITTA KAMALA WSR JAUNDICE." International Journal of Research - Granthaalayah, 6(9), 29-33. https://doi.org/10.5281/zenodo.1435210.

\section{Introduction}

In fast life style of competitive world human being taken far away from nature. Different new eating habits like Pittakara ahar like spicy food, chinese food, vada pav, missal etc. and alcohol consumption tendency also increasing day by day.

Most of times patient just come with sick and tired, later it gets diagnosed as Kamala(jaundice). The incidence of such diseases increasing day by day. Hepatocellular jaundice is a particular form of jaundice, in which skin, eyes, urine become yellowish, indicating excess bilirubin which is bile pigment in the blood. Patient also complains of fatigue and anorexia and nausea [1]. 
In all ayurvedic texts nidanapanchak and treatment of kamala given very well. "kamali tu virechana" is chikitsa sutra of kamala [2]. The treatment of kamala(jaundice) must start with virechana(purgation). Major cause is raktadushti for kamala vyadhi and yakrut (liver) is mulsthana of rakta. Rakta and pitta has ashraya-ashrayisambhanda so that a daily virechana(purgation) is recommended. The combination of some herbs is also useful in kamala chikitsa. In few conditions medication is not required, just rest and few supplement will be sufficient. In some conditions medical treatment does not work, in such case surgical help may required.

Its one attempt to management of bahupitta kamala with some ayurvedic herbs and panchakarma, which give effective result.

\section{A Case Report as Follows}

A 30 year old male patient came to us with chief complaints of [3]

- Udarshool (Aabdominal pain)

- Netragat Araktavarnata (Redness of eyes)

- Twak,Mala,Mutra,Netra pitata(Yellowness of skin,stool,urine,eyes)

- khudha mandya (Anorexia)

- hrullhas (Nausea)

Patient had above complaints since 6 months

\section{History}

No h/o - HTN, DM, asthma

\section{History of Personal Illness}

The patient was normal before 6 months ago. Since then patient had suffering from udarashula (Abdominal pain), netragata araktavarnata (Redness of eyes), twak maka mutra nrtra pittata(Yellowness of skin, stool, urine eyes), kshudha mandya(Anorexia), hrullas (Nausea). For ayurvedic treatment he came to our hospital Seth Sakharam Nemchand Jain Ayurvedic Rugnalaya in kayachikitsa dept. OPD. We admitted patient in IPD section for better management.

\section{Personal History}

Alcoholism since last 10 years.

\section{O/E-}

$\begin{array}{ll}\text { Nadi (Pulse) } & \text { - 68/min } \\ \text { Mala (Stool) } & \text { - Malavshtambha(Constipation) } \\ \text { Mutra (Urine) } & \text { - Peetavarniya } \\ \text { Jivha (Tongue) } & \text { - Samata } \\ \text { Kshudh (Apetite) } & \text { - Mandya } \\ \text { Shabdha (Speech) } & \text { - Prakrut (Normal) } \\ \text { Sparsha(Skin) } & \text { - Peetavarniya } \\ \text { Druk (Eyes) } & \text { - Arakta pitata } \\ \text { Akruti } & \text {-madhyam } \\ \text { Bal } & \text {-madhyam } \\ \text { Raktadab (BP) } & -110 / 70\end{array}$




\section{Material and Method}

1) Method

Centre of the study - S.S.N.J. ayurvedic hospital solapur.

Simple random single case study

2) Material

Table 1: Showing material of case study

\begin{tabular}{|l|l|l|l|l|}
\hline Sr. No. & Dravya & Dose & Duration & Anupan \\
\hline 1 & Nimb & $2 \mathrm{gm}$ & $\begin{array}{l}\text { 1pack(6gm) }+2 \text { cups }(100 \mathrm{ml}) \text { water } \\
\text {-Half cup }(12 \mathrm{ml})\end{array}$ & - \\
\hline 2 & Patol & $2 \mathrm{gm}$ & (Kwath nirmiti) & - \\
\hline 3 & Daruharidra & $2 \mathrm{gm}$ & & - \\
\hline 4 & Haritaki & $2 \mathrm{gm}$ & Given twice in day & - \\
\hline 5 & Kutaki & $2 \mathrm{gm}$ & & - \\
\hline 6 & Patha & $2 \mathrm{gm}$ & & - \\
\hline 7 & $\begin{array}{l}\text { Arogyavardhini } \\
\text { vati }\end{array}$ & $500 \mathrm{mg}$ & Twice in a day & Warm water \\
\hline 8 & $\begin{array}{l}\text { Mouktik yukta } \\
\text { kamdudha }\end{array}$ & $500 \mathrm{mg}$ & Twice in a day & Warm water \\
\hline 9 & Chandrakala ras & $500 \mathrm{mg}$ & Twice in a day & Warm water \\
\hline 10 & Trivruttavleha & $5 \mathrm{mg}$ & HS & Warm water \\
\hline
\end{tabular}

\section{Discussion}

Hetu of kamala [4]

\section{1) Ahar}

- madypana

- kshara-amla-lawana-usha ahar.

- viruddhara

2) Vihar

- chhardi veg dharan (Suppression of natural urges)

- divaswap (Sleeping at day time)

3) Mansika nidan

- kama,chinta,bhaya and krodha

\section{Samprapti}

Table 2: Showing the Samprapti ghatak [5]

\begin{tabular}{|l|l|}
\hline Dosh & Pitta dosh \\
\hline Dushya & Ras, Rakta, Mansa dhatu \\
\hline Adhishtana & Rakta, Mansa \\
\hline Srotas & Rasavaha,Raktavaha,Annavaha \\
\hline Vyaktisthan & Twaka \\
\hline
\end{tabular}


Table 3: Showing the Samprapti bhanga with dravyas used in chikitsa [6-14]

\begin{tabular}{|c|c|}
\hline Nimb [6] & Kandughna, pittahara, ruchya,dipan \\
\hline Patol [7] & Pittasarak,dipan,rechan,krumighna,yakrut uttejaka \\
\hline Daruharidra [8] & Kandughna, pittahara, yakrut uttejak, dipan \\
\hline Haritaki [9] & $\begin{array}{l}\text { Pittaghna, pittavirechaka, } \\
\text { anuloman,rasayani,jwaraghna,dipan,kamalahara }\end{array}$ \\
\hline Kutaki [10] & Rechak, dipan, raktashuddhikara, malabhedani \\
\hline Patha [11] & Rakatshodhak \\
\hline $\begin{array}{l}\text { Aarogyavardhini vati } \\
\text { [12] }\end{array}$ & $\begin{array}{l}\text { Regulation of pitta secretion, maintain healthy fluid level in the } \\
\text { body,agnidipan,pachana, grahanidoshnashak }\end{array}$ \\
\hline $\begin{array}{l}\text { Mouktik yukt } \\
\text { kamdudha [13] }\end{array}$ & Pittahara,dahashamak \\
\hline Chandrakala ras [14] & Pittahara,dahashamak,raktashodhak \\
\hline Trivruttavaleha & Anuloman,pittaghna \\
\hline
\end{tabular}

Table 4: Showing changes in blood investigation after chikitsa

\begin{tabular}{|l|l|l|}
\hline Test & $\mathbf{3 0 / 0 8 / 1 7}$ & $\mathbf{6 / 0 9 / 1 7}$ \\
\hline Sr. bilirubin(total) & 25.4 & 7.8 \\
\hline Sr.bilirubin(direct) & 13.2 & 5.2 \\
\hline Sr.bilirubin(indirect) & 12.2 & 2.6 \\
\hline
\end{tabular}
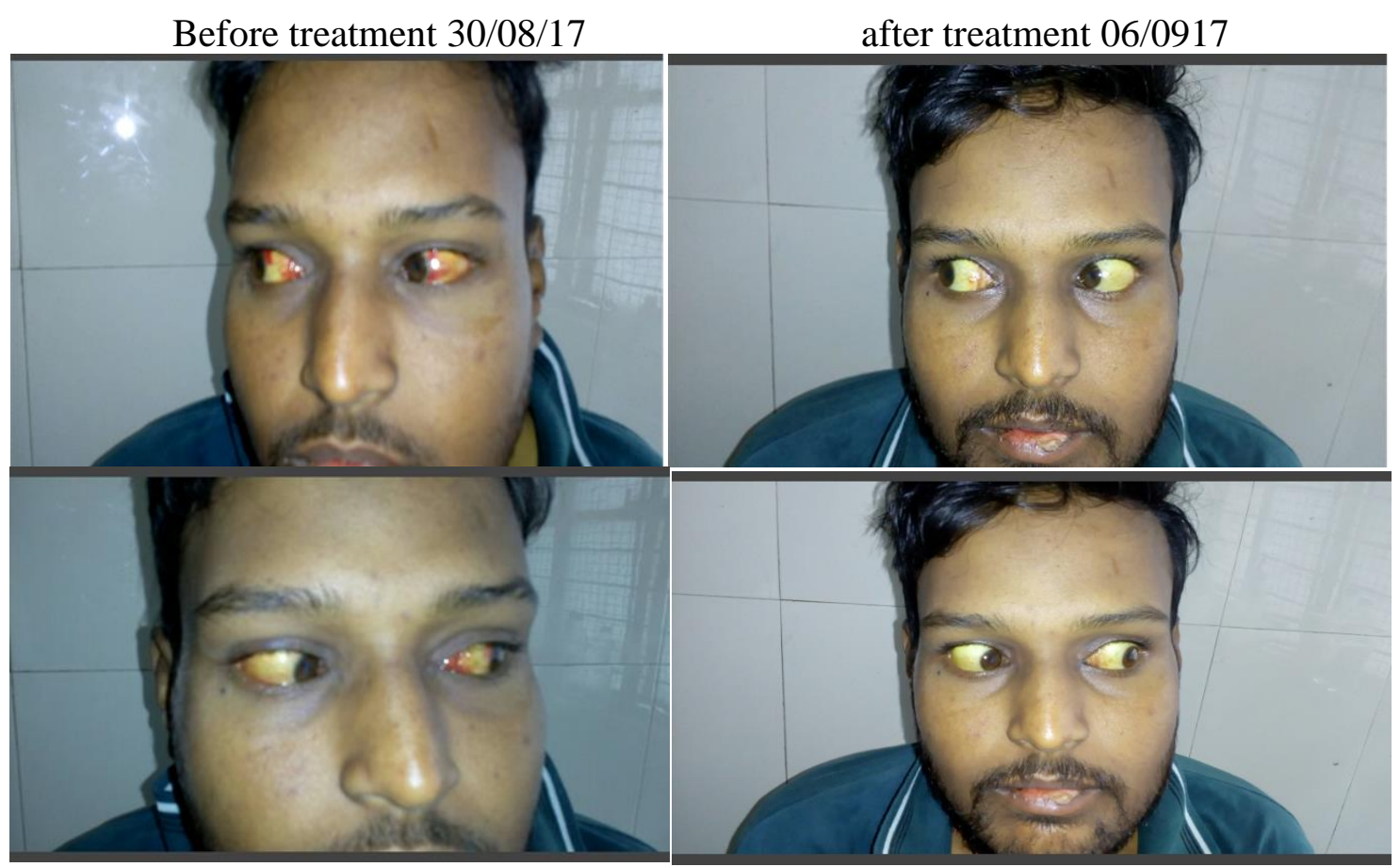

\section{Conclusion}

On the basis of above description it can be concluded that ayurved still test to time and its have details description with chikitsa of kamla(jaundice).Ayurved is much more about concerned towards the health of patient due to which there is description of a lot of medecines of jaundice 
according to the nature and nurture of patient.In bahupitta kamla mainly pitta dosha is mainly vitiated .Acharya charaka has described mrudu virechan chikitsa for bahupitta kamla.Virechan chikitsa has the quality to eliminate the vitiated dosha.Nishottar is the sukhavirechak [15].

\section{References}

[1] www.Wikipedia.org/wiki/jaundice.

[2] Joshi YG (2003)charak samhita part-2,maharshi charak,chikitsa-sthan,pandurog chikitsa adhyay.In joshi YG (Ed), vaidyamitra prakashana.(5 ${ }^{\text {th }}$ edn.),chapter 16, verse no. 40,pune,india,p. 389

[3] Joshi YG (2003)charak samhita part-2, maharshi charak,chikitsa-sthan,pandurog chikitsa adhyay.In joshi YG (Ed), vaidyamitra prakashana.( $5^{\text {th }}$ edn.),chapter 16,verse no. 40,pune,india,p. 389

[4] Joshi YG (2003)charak samhita part-2, maharshi charak,chikitsa-sthan,pandurog chikitsa adhyay.In joshi YG (Ed), vaidyamitra prakashana.( $5^{\text {th }}$ edn.),chapter 16,verse no. 40,pune,india,p. 389

[5] Joshi YG (2003)charak samhita part-2, maharshi charak,chikitsa-sthan,pandurog chikitsa adhyay.In joshi YG (Ed), vaidyamitra prakashana.( $5^{\text {th }}$ edn.), chapter 16, verse no. 40,pune,india,p. 389

[6] The ayurvedic pharmacopoea of india-part-1,Gov.of india ministry of health and family welfare dep. Of AYUSH vol-5, New delhi, india,p-152

[7] Vishnu gogate Vd (2008) Dravyagun vidnyana, plant no. 198,in: Vishnu Gogate Vd (Ed). Vaidyamitra prakashana( $1^{\text {st }}$ edition). Pune india,p-438

[8] The ayurvedic pharmacopoea of india-part-1,Gov.of india ministry of health and family welfare dep. Of AYUSH. New delhi, india,p-36

[9] Vishnu gogate Vd (2008) Dravyagun vidnyana, plant no. 198,in: Vishnu Gogate Vd (Ed). Vaidyamitra prakashana( $1^{\text {st }}$ edition). Pune india,p-688

[10] The ayurvedic pharmacopoea of india-part-1,Gov.of india ministry of health and family welfare dep. Of AYUSH vol-3, New delhi, india,p-113

[11] Prof. P.V. Sharma,Dravyaguna-vijnana,vol. 2, Chaukhambha Bharati Academy,reprint:2005,P-626

[12] Gune GP Vd (2005)Aushadhigundharmashastri,part-2,kalpa no-10.in: Gune GP Vd(Ed), reprint,india,p -208

[13] Gune GP Vd (2005)Aushadhigundharmashastri,part-2,kalpa no-20.in: Gune GP Vd(Ed), reprint,india,p -239

[14] Gune GP Vd (2005)Aushadhigundharmashastri,part-3,kalpa no-38.in: Gune GP Vd(Ed), reprint,india,p -305

[15] Yadavji trikamaji (2013) Ayurved-dipika,sansakrit commentary,charakasamhita.in: Yadavji Trikamaji (Ed) Chaukhamba-surbharati prakashan,varanasi,india,p-40-131

*Corresponding author.

E-mail address: drvaishnavisaka93@ gmail.com 